\title{
Public Health of United Territorial Communities in Ukraine
}

\author{
Roman Hrytsko \\ Department of Infectious Diseases, Danylo Halytsky Lviv National Medical University, Lviv, Ukraine \\ Email address: \\ grj3@3g.ua \\ To cite this article: \\ Roman Hrytsko. Public Health of United Territorial Communities in Ukraine. Journal of Family Medicine and Health Care. \\ Vol. 5, No. 3, 2019, pp. 28-31. doi: 10.11648/j.jfmhc.20190503.11
}

Received: April 3, 2019; Accepted: June 24, 2019; Published: August 26, 2019

\begin{abstract}
The article highlights basic principles of state and public administration of individual health care and public health care of united territorial communities, which are the basis for public community in Ukraine. With the adaptation of the Law of Ukraine "On deliberate union of territorial communities", a new stage of decentralization of state power, reforms of local government as well as administrative and territorial reforms started in Ukraine. Distribution of budget for health care between district budget and budget of united territorial communities required organizational and structural division of health care system, which provided medical care for individuals of corresponding residential areas. Depending on the health group and the diagnosis, a complex of rehabilitating and restorative curative measures is developed for the formation, preservation and strengthening health of the healthy and for restoration of health of the sick people in the following year. The integrative function of family doctors of the united territorial communities allows to provide: the unified process of formation, preservation and strengthening health of the healthy people of various age and gender groups; early disease detection, primary prevention of diseases, remedial treatment and medical and social rehabilitation of patients and injured people with high quality and efficacy.
\end{abstract}

Keywords: United Territorial Communities, Public Health, Integrative Family Medicine, State and Public Administration of Public Health, Record of Public Health

\section{Introduction}

The Constitution of Ukraine defines that management of rural health care establishments is performed by territorial communities of villages and urban villages directly via created local government authorities. In the system of local administration, territorial community is the primary element of villages, urban villages and towns, which has the rights to solve problems at local level within the Constitution and laws of Ukraine. These rights include elaboration of the programs of social and cultural development, target programs of regulation of public relations in public health care [1].

Special attention is paid to public health care, measures regarding prevention of diseases, improvement of public health and prolonging the duration of individuals' productive life [2-4].

An important role of local government authorities is stated in the Decree of the President of Ukraine "On conception of the development of public health care in Ukraine" [5] dated 07.02.2000 № 1313. It emphasizes that territorial community provides a control over services and financial issues of public health care, and its major part should be provided at the level of primary medical care based on family medicine.

Family medicine in Ukraine is based on prophylactic measures of specialists' work, which integrates the notions of family medicine in clinics - family - territorial community family doctor and involves specialist physicians to improve the condition of public health of residents of combined territorial communities.

Community is a collection of individuals, united due to certain conditions or circumstances. Most commonly, such condition is the geographical territory where certain population lives: village, urban village, town, as well as family territorial community. Communities can also be defined by other criteria: common workplace, profession, common culture, religious denomination etc.

\section{Method}

Public health is the condition of demographic structure, physical and intellectual potential, moral and psychological 
climate, which provides certain level of life in the community and performance of other social functions within historical period of time $[6,7]$.

Public health involves all aspects associated with health of each individual of the community (resident), but it is not limited to only characteristics of individual health of community members.

Most frequently, definition "individual health" is used in preliminary statement of the statute of World Health Organization (WHO). In this definition, social (public) criterion of health is considered along with such traditional criteria as physical (somatic) and mental (psychic). Inseparability of biological and social aspects in human nature makes such approach to health care of the individuals justified.

Physical and social wellbeing of an individual provides capability to fulfill the following vital functions, as ability to perform physical work (mobility, working ability), cognitive activity (perception, remembering and interpreting information, adequate emotional evaluation of events in the environment and one's place in it, reproduction and birth of healthy offspring, as well as ability to differentiate between notions "self-not self" based on cell-mediated and humoral immunities. It allows to state that the definition of public health is referred to somatic, mental, immunological and reproductive health of each individual.

With the adaptation of the Law of Ukraine "On deliberate union of territorial communities" dated 05.02.2015 №157VIII, a new stage of decentralization of state power, reforms of local government as well as administrative and territorial reforms started in Ukraine. Amendments were also made to budget and tax laws aimed at providing united territorial communities with financial independence via adoption of respective rights, revenues and expenses. They were taken into account for determination of inter-budget relationship with state budget by providing direct state donations and subventions [8].

Similar to districts, united territorial communities received and became holders of medical subvention for primary medical care directly from state budget. Amount of this medical subvention, as for a district, is calculated according to a certain formula depending on the number of the population.

Distribution of budget for health care between district budget and budget of united territorial communities required organizational and structural division of health care system, which provided medical care for individuals of corresponding residential areas.

According to the Law of Ukraine "On amendments to Fundamentals of legislation of Ukraine on health care regarding improvement of providing medical care" dated 07.07.2011, № 3611-VI, a family doctor, who provides primary medical care for united territorial community and is a public doctor, has the right to coordinate and integrate professional activities of any specialist in health care system of the country in order to deal with the problems of a patient and public health of territorial community [9].
In his scientific pursuits, Professor V. P. Voytenko [10] expressed his sound opinion that in the process of development of any disease in the human body there remain greater or smaller numbers of the signs of health, and in the practical work of doctors in Ukraine all patients were divided into 5 groups of public health $[11,12]$ in the course of organization of medical care by way of prophylactic medical examination:

1st group - healthy people who do not complain about their health and have no objective signs of illness at the time of examination and had not been ill in the past;

2nd group - practically healthy people, whose history shows diseases they had in the past and the risk factors for the development of a particular pathology but who do not complain at the time of examination;

3rd group - patients with chronic diseases in the stage of compensation;

4th group - patients with chronic diseases in the stage of subcompensation;

5 th group - patients with chronic diseases in the stage of decompensation.

Communal 5th City Clinical Polyclinic in Lviv (Ukraine), that on the order of the Department of Public Health of Lviv City Council «On introduction of the model of providing general and specialist medical services on the principles of family medicine in the communal 5th City Clinical Polyclinic in the city of Lviv» \#24-B of 21.03.2004 was reorganized in 2004 into the clinic of integrative family medicine, holds the leading positions in modernization of family medicine in the city of Lviv on the regional level. In this complex and comprehensive process, a leading role belongs to the center of primary medical care, where 80 family doctors and 94 nurses work in 59 family territorial communities. Along with family medicine, specialist physicians also provide medical care in the same establishment. They work in a consulting therapeutic and diagnostic center and are focused on formation, maintenance and improvement of wellbeing of each healthy individual and health recovery of patients in one of the administrative districts of Lviv city. Doctors in the aforementioned establishment of health care improve public health of the residents within territorial community of one district in Lviv.

Specialists of integrative family medicine clinic, working in family territorial communities, actively involve state and local authorities, professionals of specialized and highly specialized medical care in the formation, maintenance and improvement of wellbeing of healthy residents of various age groups and recovery of health of ill individuals in united territorial communities.

Integrating efforts, united territorial community, via certain individuals and public organizations, participates not only in improving health of its residents and in forming high level of public health, but also draws a public scheme of health care, which is an important component of public health care that is being developed in Ukraine. 


\section{Result}

Depending on the health group and the diagnosis, a complex of rehabilitating and restorative curative measures has been developed for the formation, preservation and strengthening health of the healthy individuals and for restoration of health of the sick people in the following year.

Table 1. Distribution of patients by health condition.

\begin{tabular}{|c|c|c|c|c|c|c|c|c|c|c|c|c|}
\hline Health group & \multicolumn{4}{|c|}{ Healthy } & \multicolumn{6}{|l|}{ Sick } & \multirow{2}{*}{\multicolumn{2}{|c|}{ Total }} \\
\hline \multirow[t]{2}{*}{ Age, years } & \multicolumn{2}{|c|}{$\begin{array}{l}\text { I group } \\
\text { (healthy) }\end{array}$} & \multicolumn{2}{|c|}{$\begin{array}{l}\text { II group (practically } \\
\text { healthy) }\end{array}$} & \multicolumn{2}{|c|}{$\begin{array}{l}\text { III group } \\
\text { (compensation stage) }\end{array}$} & \multicolumn{2}{|c|}{$\begin{array}{l}\text { IV group } \\
\text { (subcompensation stage) }\end{array}$} & \multicolumn{2}{|c|}{$\begin{array}{l}\text { V group } \\
\text { (decompensation } \\
\text { stage) } \\
\end{array}$} & & \\
\hline & M & $\mathbf{F}$ & M & $\mathbf{F}$ & M & $\mathbf{F}$ & M & $\mathbf{F}$ & M & $\mathbf{F}$ & M & $\mathbf{F}$ \\
\hline \multirow{7}{*}{$\begin{array}{l}\text { Under } 3 \\
\text { years } \% \text {, abs. } \\
3-6 \text { years\%, } \\
\text { abs. } \\
7-14 \\
\text { years } \% \text {, abs. } \\
15-18 \text { years } \\
\% \text {, abs. }\end{array}$} & \multirow{2}{*}{45.4} & \multirow{2}{*}{35.3} & \multirow{2}{*}{41.9} & \multirow{2}{*}{42.6} & \multirow{2}{*}{12.2} & \multirow{2}{*}{21.8} & \multirow{2}{*}{0.5} & \multirow{2}{*}{0.2} & \multirow{2}{*}{0.1} & \multirow{2}{*}{0.1} & $100 \%$ & $100 \%$ \\
\hline & & & & & & & & & & & 1108 & 1372 \\
\hline & 44.5 & 35.7 & 38.6 & 42.1 & 15.7 & 21.6 & 1.0 & 0.4 & 0.2 & 0.2 & $100 \%$ & $100 \%$ \\
\hline & \multirow{2}{*}{44,6} & \multirow{2}{*}{40.5} & \multirow{2}{*}{46.0} & \multirow{2}{*}{47.4} & 7.8 & 11.4 & 1.4 & 0.6 & 0.2 & 0.1 & $100 \%$ & $100 \%$ \\
\hline & & & & & & & & & & 0.1 & 2980 & 3115 \\
\hline & 43.3 & 35.0 & 45.1 & 46.5 & 10.8 & 20.1 & 0.6 & 0.1 & 0.2 & 0.2 & $100 \%$ & $100 \%$ \\
\hline & 75.0 & 35.0 & $4 J .1$ & 40.0 & 10.0 & 20.1 & 0.0 & 0.1 & 0.2 & 0.2 & 1975 & 2623 \\
\hline $19-60$ years & 28.5 & 191 & 312 & 254 & 420 & 423 & 41 & 48 & 42 & 44 & $100 \%$ & $100 \%$ \\
\hline$\%$, abs. & 20.5 & 19.1 & 31.2 & 25.4 & 42.0 & 42.3 & 4.1 & 4.0 & 4.2 & 4.4 & 26333 & 25691 \\
\hline Over 60 years & 14 & 13 & 204 & 139 & 569 & 639 & 100 & 101 & 113 & 109 & $100 \%$ & $100 \%$ \\
\hline Total $\%$, abs. & 19.3 & 18.6 & 31.213072 & 29.212839 & 39.8 & 42.118510 & 4.81998 & 5.12254 & 4.92174 & 5.02179 & $100 \%$ & $100 \%$ \\
\hline Torut & 8180 & 8199 & 2010 & 25.212053 & 16670 & T2.110010 & מ & & $4.921 / 4$ & 5.02179 & 41922 & 43980 \\
\hline
\end{tabular}

\section{Discussion}

Under the present day conditions, the national health care system of any country is a complicated and extremely costly sphere of functioning of the society, and an ineffective health care system turns into an ever-growing threat to the social and economic development of the state and its security.

Despite the fact that so far no perfect comprehensive mechanism of public health management in public health has been developed in any of the countries, scientists and politicians in Ukraine express their confidence that family doctors working in a well-organized health care system on the principles of integrative family medicine and have the opportunity to improve constantly their qualification on the basis of continuous professional development, can improve the state of public health in the united territorial communities.

However, without a comprehensive reform of the health care system of Ukraine and the establishment of civil society institutions that will address directly protection of health of individual citizens and public health of the united territorial communities both, on the local and national levels, it will be impossible to create a modern effective healthcare system.

\section{Conclusions}

Based on the above the following conclusions can be made:

i. Government control of public health of the united territorial communities can be realized on the basis of health register prepared by the family doctors of the family territorial areas.

ii. Proceeding from the results of monitoring indices of the united territorial community health register the family medicine experts develop comprehensive plans for preservation and strengthening health of the healthy citizens of various age and gender groups, and for restoring health of the ill citizens, for their medical and social rehabilitation, involving in these processes specialists of the health care establishments of the II and III levels.

iii. The integrative function of family doctors of the united territorial communities allows to provide:

a. The unified process of formation, preservation and strengthening health of the healthy people of various age and gender groups;

b. Early disease detection, primary prevention of diseases, remedial treatment and medical and social rehabilitation of patients and injured people with high quality and efficacy;

c. Opportunities for a harmonious patient-oriented combination of professional interests of the integrated medical care with the use of human and technological resources of state health care system and the system of the united territorial communities;

d. The optimal form of combining interests of the territorial and sectoral management in the system of the state-public regulation of public health care of the united territorial communities in one territorial space.

iv. Improvement of scientific and practical links with the international structures in various countries, that provide medical care on the basis of public health care system, promotes raising the level of continuous professional development of the family medicine specialists for strengthening public health of the united territorial communities. 


\section{References}

[1] Constitution of Ukraine. - Kyiv: Prosvita, 1996. - p.80.

[2] Clinic of integrative family medicine /Ed. B. Lemishka, Ye. Zaremba, A. Bazylevych. - Lviv: Spolom, p.335.

[3] Hrytsko R. Y., Furtak I. I. Mechanisms of integrating model of medicine in the processes of optimization of funding and structure of medical aid // International research and practice conference "Paragraphs in medicine": Conference proceedings, March 9, 2017. Lublin: Izdevnieciba "Baltija Publishing”. 176 pages. ISBN 978-9934-571-46-6 (P. 150153).

[4] Hrytsko R. Y., Furtak I. I. Model of integrated medicine in Ukraine // Międzynarodowa konferencja nauko-wopraktyczna "Innowacyjne technologie w medycynie: doświadczenia Polski i Ukrainy". Lublin, Polska 28-29 kwiecień, 2017 - P. 113-116.

[5] On the concept of development of public health of the population of Ukraine / Decree of the President of Ukraine \# 989 of 20.06.2000. // Medychnyy Visnyk Ukrayiny. - 200. \#25. - p. 3

[6] Public health and public nursing. Ed. Prof. Ye. Ya. Sklyarova, M. B. Shehedyn, B. B. Lemishka. - Kyiv.: Medicine, 2008. p. 223.

[7] Hrytsko R. Y., Furtak I. I. Management of anti-crisis measures in the system of health care in Ukraine currently // Key issues of education and sciences: development prospects for Ukraine and Poland. International multidisciplinary conference Stalowa Wola, RP, 20-21 july 2018. Vol. 5. Stalowa Wola: "Baltija Publishing" 2018. 208 p. (P. 35-41.)

[8] On voluntary association of communities / Law of Ukraine \#157-VIII of 05.02.2015.

[9] On changes in the principles of legislation of Ukraine on public health pertaining to the improvement of health care / Law of Ukraine \# 3611-VI of 07.07.2011.

[10] Voytenko V. P. Health of the healthy - introduction to sanology / V. P. Voytenko. - Kyiv: Zdorovya, 1991.- p. 246.

[11] Hrytsko R. Yu. State administration of family medicine specialists'education system in Ukraine / R. Yu. Hrytsko. Drohobych: Posvit, 2014. - p. 363 - p. 95-101.

[12] Hrytsko R. Y. Role of family medicine specialists of unified territorial communities in fulfilling mechanisms of state administration of public health by transplantating anatomic human materials // State and regions. Series: State administration - 2018, № 4. - P. 52-58. 